\title{
Smoking patterns at different medical schools in Turkey
}

Ali Kocabaş, Refik Burgut, Nafiz Bozdemir, Atilla Akkoçlu, Orhan Çildağ, Elif Dağli, Levent Erkan, Recep Işik, Haluk Türktaş

\begin{abstract}
Objective - To assess smoking-related behaviour, beliefs, and attitudes of students at different medical schools in Turkey, in comparison to those of students in nonmedical schools.
\end{abstract}

Design-First- and final-year medical and nonmedical (science) students from seven universities located in different geographical areas in Turkey replied anonymously to an adapted World Health Organisation questionnaire in Turkish.

Subjects-First-, fourth- and sixth(final) year medical students (total 3073) and first- and fourth- (final) year nonmedical students (total 2401) from different universities.

Results - The prevalence of daily smoking among first-year medical students (both sexes combined) was $11.8 \%$ (range $8.7-14.9 \%$ for the universities), significantly lower than that of nonmedical first-year students $(21.0 \%$, range 12.1 $28.4 \%)(p<0.01)$. For the final year the difference did not reach significance: medical students $30.2 \%$ (range 23.0-38.7\%), nonmedical $32.5 \%$ (range $21.1-48.7 \%$ ) (p > 0.05). Daily smoking prevalence for medical students was three times higher among males $(30.5 \%)$ than females $(10.1 \%)$, but was twice as high in nonmedical students $(32.4 \%$ for males and $16.4 \%$ for females). A serious attempt to quit had been made by $45.0 \%$ of smokers in medical and $47.9 \%$ in nonmedical schools $(p>0.05) ; 30.6 \%$ of smokers in medical and $27.2 \%$ in nonmedical schools thought that they would no longer smoke in five years' time ( $p>$ $0.05) .87 .9 \%$ of medical and $85.7 \%$ of nonmedical students believed smoking to be harmful to health. In medical schools, there were important defects in knowledge of smoking as a major cause of pulmonary emphysema, coronary artery disease, peripheral vascular disease, neonatal mortality, and bladder cancer. There were also important defects both in knowledge and motivation regarding counselling patients to stop smoking and the role of doctors in antismoking campaigns. Legislative measures against smoking were equally likely to be supported by medical and nonmedical students.
Conclusions-Smoking was much more prevalent among Turkish than among US, Australian, European, Asian (including Japan but not Russia) and African medical students. This study indicates that the current system of medical education in Turkey has little or no effect on the attitudes and behaviour of students regarding smoking.

(Tobacco Control 1994; 3: 228-235)

\section{Introduction}

The general health of people throughout the world, especially in developing countries, is greatly threatened by cigarette smoking, which has reached epidemic proportions in the last 25 years. The lack of antitobacco organisations, the tremendous effort of international tobacco cartels to increase market share, and the addictive nature of nicotine are responsible for the high level of epidemic in many developing countries. ${ }^{1,2}$

With professional expertise in smokingrelated diseases and nicotine addiction, physicians should play a particularly important role in tobacco control. This can be enhanced in their everyday contact with the public and by their personal example as nonsmokers. However, in many countries they have yet to make an effective contribution, perhaps because they have not yet been made aware of the challenge and of their responsibility to meet it. Understandably, this is particularly true of doctors who smoke ${ }^{3,4}$ Medical schools, therefore, have a particular responsibility to inculcate appropriate knowledge, attitudes, behaviour and sense of responsibility in the next generation of doctors.

Studies conducted on more than 5000 medical students in 42 countries by the Tobacco and Health Committee of the International Union Against Tuberculosis and Lung Disease (IUATLD) revealed serious deficiencies in knowledge, attitudes, and behaviour regarding smoking. Appropriate changes in curricula were urgently recommended. ${ }^{5-8}$

Turkey, which is a tobacco-producing country, has also been seriously affected by the world smoking epidemic. The entrance of multinational tobacco companies into the Turkish market since 1984 has contributed to even higher levels of smoking. The multinational companies are aiming to increase cigarette 
sales not only in Turkey but also in the Middle East, Eastern Europe and in Asian countries by way of Turkish factories, which are about to become operational. In future years this will pose a major threat to the health of people living in the region. Even now, cigarette consumption per person in Turkey has become one of the highest in Europe. ${ }^{9,10}$ In Turkey, where there are no effective antismoking activities, smoking prevalence for physicians is not significantly different from that of the general population. ${ }^{11}$ This led us to review the current medical curriculum concerning smoking and to conduct the present study.

The aims of the study were: $a$ ) to examine the smoking behaviour, knowledge, and attitudes towards smoking of students from seven medical schools located in different regions of Turkey, and to obtain baseline data against which future changes could be measured; $b$ ) to compare students' behaviour towards smoking in similar classes of medical and nonmedical schools of the same universities to help determine the effect of medical education on the smoking measures in our survey.

\section{Methods}

This study, conducted between November 1990 and February 1991, was carried out on medical and nonmedical (science) students from seven universities. One university was randomly selected from each of the seven geographic regions of Turkey, from among the total of 23 universities in the country. Medical education in Turkey lasts for six years, nonmedical education for four years. In order to make comparisons possible, fourth-year medical students were also assessed. Medical students in the first, fourth and final year, and nonmedical students in the first and final (fourth) year, from the Cukurova, Dokuzeylul, Ataturk, Marmara, Ondokuzmayis, Dicle, and Gazi Universities, were included in the study.

The adapted questionnaire used in this study was based on the one designed for health professionals by the World Health Organisation (WHO) in cooperation with the International Union Against Cancer (UICC) and the American Cancer Society (ACS), ${ }^{12}$ and used in the previous IUATLD studies. This enables us to compare our findings with those of the IUATLD. ${ }^{5-8}$ Two sets of questionnaires, one for medical and one for nonmedical students, were finalised after a pilot study on a group of medical and nonmedical students. They were administered to the students in a single session by the coordinator responsible for each university; students were asked to respond freely and truthfully to each question.

Our aim was to obtain responses from all the students. Inevitably some students were absent from the class at the time of the study. Average participation rates in the study were $88 \%$ (range $82-94 \%$ between universities) for firstyear, $86 \%$ (range $81-94 \%$ ) for fourth-year and $85 \%$ (range $82-97 \%$ ) for final- (sixth) year medical students. All the students present in the class participated in the survey voluntarily. Not all questions were answered by all students, resulting in different totals in some tables. A similar number of nonmedical students in the first and fourth years were randomly selected and a corresponding questionnaire administered. In nonmedical schools, average participation rates were $95 \%$ (range $88-99 \%$ ) for first-year and $82 \%$ (range 77$89 \%$ ) for final- (fourth) year students.

In this study, students' smoking status was classified according to the $\mathrm{WHO}^{12}$ as follows: Daily smokers: anyone who, at the time of survey, smokes some kind of tobacco product at least once a day. Occasional smokers: anyone who smokes, but less than once a day. Exsmokers: anyone who smoked daily for at least six months, but who did not smoke at the time of survey. Never-smokers: anyone who has never smoked.

The analysis was carried out in the computer centre of the Çukurova University using SPSS-X. The chi-square test or, where appropriate, Fisher's exact test and analysis of variance techniques were used for the comparison of categorical and continuous variables, respectively.

\section{Results}

DEMOGRAPHIC DATA

The total numbers analysed were 5474, 3073 from medical and 2401 from nonmedical schools. Of 3073 medical students, 1068 were in the first year, 1235 in the fourth year and 770 in their final year. Females comprised $35.5 \%$ of medical students (range $22.1-52.0 \%$ for different universities; $\mathrm{p}<0.0001)$. The mean age for the medical students was 19.0 years for the first curriculum year (range $18.7-19.4) ; 22.2$ years for the fourth year (range 21.8-22.9); and 23.3 years for the final year (range 23.3-24.7).

Of 2401 nonmedical students, 1366 students were in the first year and 1305 in the fourth (final) year. Of these, $40.1 \%$ were female (range $22.1-48.4 \%$ for different universities; $\mathrm{p}<0.001$ ).

The average age for medical students was lower than the average age for nonmedical student within the same curriculum years $(\mathrm{p}<$ $0.01)$. Only a small proportion $(10 \%)$ of both medical and nonmedical students came from rural areas and there were no differences between universities $(\mathrm{p}>0.05)$.

\section{SMOKING STATUS}

The smoking status of both medical and nonmedical students by gender and curriculum year is shown in table 1 . In both medical and nonmedical schools, the overall prevalence rates for daily smoking among both male and female students increased significantly from first to final years $(p<0.0001)$. The rate of increase in smoking prevalence from first to final year among female medical students was higher than that in male students. The daily smoking prevalence rate for medical students, both sexes combined, rose to $30.2 \%$ in the final year from $11.8 \%$ in the first year. Rates for daily and occasional smoking rose to $49.5 \%$ 
Table 1 Smoking status of medical and nonmedical students by curriculum year and gender (all universities)

\begin{tabular}{|c|c|c|c|c|c|c|c|c|c|c|c|}
\hline \multirow[b]{2}{*}{ Schools } & \multirow{2}{*}{$\begin{array}{l}\text { Curriculum } \\
\text { year }\end{array}$} & \multicolumn{2}{|c|}{$\begin{array}{c}\text { Daily } \\
\text { smokers }(\%)\end{array}$} & \multicolumn{2}{|c|}{$\begin{array}{c}\text { Occasional } \\
\text { smokers }(\%)\end{array}$} & \multicolumn{2}{|c|}{$\begin{array}{c}\text { Ex- } \\
\text { smokers (\%) }\end{array}$} & \multicolumn{2}{|c|}{$\begin{array}{c}\text { Never- } \\
\text { smokers (\%) }\end{array}$} & \multicolumn{2}{|c|}{$\underset{(n)}{A l l}$} \\
\hline & & $m$ & $f$ & $m$ & $f$ & $m$ & $f$ & $m$ & f & $m$ & $f$ \\
\hline \multicolumn{12}{|l|}{ Medical } \\
\hline & $\begin{array}{l}1 \mathrm{st} \\
4 \text { th } \\
6 \text { th (final) }\end{array}$ & $\begin{array}{l}17.6 \\
35.9 \\
37.1\end{array}$ & $\begin{array}{r}3.8 \\
12.8 \\
16.9\end{array}$ & $\begin{array}{l}17.4 \\
17.1 \\
19.8\end{array}$ & $\begin{array}{r}9.0 \\
13.6 \\
18.0\end{array}$ & $\begin{array}{l}3.2 \\
5.4 \\
3.7\end{array}$ & $\begin{array}{l}0.9 \\
1.3 \\
3.8\end{array}$ & $\begin{array}{l}61.8 \\
41.6 \\
39.3\end{array}$ & $\begin{array}{l}86.3 \\
72.3 \\
61.3\end{array}$ & $\begin{array}{l}622 \\
852 \\
509\end{array}$ & $\begin{array}{l}446 \\
383 \\
261\end{array}$ \\
\hline & Total & 30.5 & 10.1 & 17.9 & 12.8 & 4.2 & 1.7 & 47.3 & 75.4 & 1983 & 1090 \\
\hline \multicolumn{12}{|c|}{ Nonmedical } \\
\hline & $\begin{array}{l}1 \text { st } \\
4 \text { th (final) }\end{array}$ & $\begin{array}{l}26.4 \\
41.5\end{array}$ & $\begin{array}{l}11.8 \\
21.4\end{array}$ & $\begin{array}{l}15.8 \\
15.7\end{array}$ & $\begin{array}{l}15.4 \\
14.1\end{array}$ & $\begin{array}{l}4.3 \\
5.8\end{array}$ & $\begin{array}{l}1.8 \\
4.3\end{array}$ & $\begin{array}{l}53.5 \\
37.0\end{array}$ & $\begin{array}{l}71.1 \\
60.2\end{array}$ & $\begin{array}{l}865 \\
573\end{array}$ & $\begin{array}{l}501 \\
462\end{array}$ \\
\hline & Total & 32.4 & 16.4 & 15.3 & 14.7 & 4.7 & 3.0 & 45.5 & 65.8 & 1438 & 963 \\
\hline
\end{tabular}

$\mathrm{m}=$ male, $\mathrm{f}=$ female.

Table 2 Smoking status of medical students in different medical schools by gender, first-, fourth-, and final-year students combined

\begin{tabular}{|c|c|c|c|c|c|c|c|c|c|c|}
\hline \multirow[b]{2}{*}{ Medical schools } & \multicolumn{2}{|c|}{$\begin{array}{c}\text { Daily } \\
\text { smokers }(\%)\end{array}$} & \multicolumn{2}{|c|}{$\begin{array}{c}\text { Occasional } \\
\text { smokers }(\%)\end{array}$} & \multicolumn{2}{|c|}{$\begin{array}{c}\text { Ex- } \\
\text { smokers }(\%)\end{array}$} & \multicolumn{2}{|c|}{$\begin{array}{c}\text { Never- } \\
\text { smokers }(\%)\end{array}$} & \multicolumn{2}{|c|}{$\underset{(n)}{\text { All students }}$} \\
\hline & $m$ & $f$ & $m$ & $f$ & $m$ & $f$ & $m$ & $f$ & $m$ & $f$ \\
\hline $\begin{array}{l}\text { Çukurova } \\
\text { Dicle } \\
\text { Atatürk } \\
\text { Gazi } \\
\text { Dokuzeylül } \\
\text { Ondokuz mayis } \\
\text { Marmara }\end{array}$ & $\begin{array}{l}28.7 \\
30.5 \\
35.1 \\
33.0 \\
31.4 \\
26.5 \\
26.2\end{array}$ & $\begin{array}{r}9.1 \\
5.5 \\
9.8 \\
13.9 \\
9.6 \\
9.3 \\
10.0\end{array}$ & $\begin{array}{l}17.7 \\
20.5 \\
20.4 \\
16.0 \\
12.1 \\
18.9 \\
19.3\end{array}$ & $\begin{array}{r}12.0 \\
5.5 \\
14.6 \\
13.9 \\
11.7 \\
12.2 \\
18.0\end{array}$ & $\begin{array}{l}3.9 \\
3.1 \\
4.1 \\
4.5 \\
3.9 \\
5.1 \\
6.9\end{array}$ & $\begin{array}{l}1.0 \\
2.7 \\
0.8 \\
0.9 \\
2.0 \\
1.7 \\
5.0\end{array}$ & $\begin{array}{l}49.7 \\
45.7 \\
40.1 \\
46.5 \\
52.5 \\
49.5 \\
47.5\end{array}$ & $\begin{array}{l}78.0 \\
86.3 \\
74.8 \\
71.3 \\
76.6 \\
76.7 \\
67.0\end{array}$ & $\begin{array}{l}457 \\
258 \\
368 \\
200 \\
280 \\
275 \\
145\end{array}$ & $\begin{array}{r}209 \\
73 \\
123 \\
216 \\
197 \\
172 \\
100\end{array}$ \\
\hline Total ( $\left.{ }^{\star}\right)$ & 30.5 & 10.1 & 17.9 & 12.8 & 4.3 & 1.7 & 47.4 & 75.4 & 1983 & 1090 \\
\hline
\end{tabular}

${ }^{\star} \mathrm{p}<0.001$ between figures for males and females for each smoking category.

$\mathrm{m}=$ male, $\mathrm{f}=$ female.

in final-year medical students from $25.6 \%$ in the first year.

In both medical and nonmedical schools, smoking rates were higher among males than among females $(\mathrm{p}<0.0001)$. The rate for daily smoking among medical students was, on average, three times higher in males $(30.5 \%)$ than in females $(10.1 \%)$. Among nonmedical students, this ratio was about twofold.

The daily smoking rate for male medical students was $17.6 \%$ for the first year (range $14.1-22.8 \%$ for the different universities), $35.9 \%$ for the fourth year (range $25.9-47.6 \%$ ), and $37.1 \%$ for the final year (range 30.1$43.8 \%$ ). Corresponding figures for female medical students were $3.8 \%$ (range 1.4$6.4 \%$ ), $12.8 \%$ (range $4.0-16.9 \%$ ), and $16.9 \%$ (range 8.2-27.9\%) (table 1). For nonmedical schools, daily smoking rates were $26.4 \%$ for males and $11.8 \%$ for females in the first year. The corresponding figures in the final year were $41.5 \%$ for males and $21.4 \%$ for females.

Combining daily with occasional smokers, first-year male medical students smoked less $(35.0 \%)$ than first year male nonmedical students $(42.2 \%)(\mathrm{p}<0.001)$. This also held for first year female students $(12.8 \%$ vs $27.2 \%)$ $(\mathrm{p}<0.001)$. In the fourth year, smoking rates of medical $(53.0 \%)$ and nonmedical $(57.2 \%)$ male students were similar $(p>0.05)$, but female students were significantly different; fewer female medical students $(26.4 \%)$ smoked than female nonmedical students $(35.5 \%)(\mathrm{p}<0.001)$.

Smoking status of medical students from different universities by gender (first, fourth and final year students combined) is assessed separately for different universities in table 2 . There were significant variations in smoking prevalence (daily and occasional smokers combined) among different medical schools. Smoking prevalence was $48.4 \%$ (range $43.6-$ $55.4 \%$ for the different medical schools, $\mathrm{p}<$ 0.05 ) for male medical students and $22.9 \%$ (range $11.0-28.0 \%, p=0.07$ ) for female medical students. Smoking rates for nonmedical students among different universities also showed significant variations $(\mathrm{p}<0.01)$; smoking prevalence was $48.2 \%$ (range 33.8$56.5 \%$ ) among males and $31.2 \%$ (range: $24.1-46.7 \%$ ) among female nonmedical students (first and final years combined).

The average number of cigarettes smoked daily was 16.6 by medical students and 16.2 for nonmedical students. The number of cigarettes smoked daily by medical and nonmedical students did not differ significantly by school or curriculum year $(p>0.05)$. Male smokers in either medical or nonmedical schools smoked more daily than female students $(16.9$ vs 14.1) ( $\mathbf{p}<0.0001)$. All of the students in the study smoked manufactured cigarettes and $97 \%$ smoked filtered cigarettes.

\section{STOPPING SMOKING}

The proportions of ex-smokers among both medical and nonmedical students was low (3.4\% and $4.1 \%$, respectively); $74 \%$ of medical students of both sexes had thought of stopping smoking, and $45 \%$ had made at least one serious attempt to do so. In this respect there were no significant differences between medical and nonmedical students, between universities or between curriculum years when both sexes were combined (table 3).

The responses to the question " What do you think your smoking habit will be in five 
Table 3 Percentage of medical and nonmedical smoker students who have thought of giving up smoking and have actually made a serious attempt to stop smoking, by year and gender

\begin{tabular}{|c|c|c|c|c|c|c|c|c|c|c|}
\hline & \multicolumn{6}{|c|}{ Medical students (\%) } & \multicolumn{4}{|c|}{ Nonmedical students $(\%)$} \\
\hline & \multicolumn{2}{|c|}{ First year } & \multicolumn{2}{|c|}{ Fourth year } & \multicolumn{2}{|c|}{ Final year } & \multicolumn{2}{|c|}{ First year } & \multicolumn{2}{|c|}{ Final year } \\
\hline & $\begin{array}{c}m \\
(n=217)\end{array}$ & $(n=57)$ & $\begin{array}{c}m \\
(n=450)\end{array}$ & $\begin{array}{c}f \\
(n=101)\end{array}$ & $\begin{array}{c}m \\
(n=290)\end{array}$ & $(n=91)$ & $\begin{array}{c}m \\
(n=36\end{array}$ & $\begin{array}{c}f \\
(n=136)\end{array}$ & $\begin{array}{c}m \\
(n=328)\end{array}$ & $\begin{array}{c}f \\
(n=164)\end{array}$ \\
\hline $\begin{array}{l}\text { Thought of } \\
\text { giving up }\end{array}$ & 77.2 & 67.3 & 67.5 & 51.9 & 71.8 & 65.0 & 76.2 & 70.5 & 76.3 & 73.4 \\
\hline $\begin{array}{l}\text { Serious attempt } \\
\text { to stop smoking }\end{array}$ & 48.9 & 31.9 & 48.0 & 29.2 & 47.6 & 36.4 & 50.1 & 39.7 & 50.8 & 43.7 \\
\hline
\end{tabular}

Table 4 "What do you think your smoking habits will be five years from now?" Percentage of answers for medical and nonmedical students according to their smoking status, males and females combined

\begin{tabular}{|c|c|c|c|c|c|c|c|c|}
\hline & \multicolumn{4}{|c|}{ Medical students (\%) } & \multicolumn{4}{|c|}{ Nonmedical students ( $\%)$} \\
\hline & $\begin{array}{c}\text { Daily } \\
\text { smokers } \\
(n=702)\end{array}$ & $\begin{array}{c}\text { Occasional } \\
\text { smokers } \\
(n=475)\end{array}$ & $\begin{array}{c}\text { Ex- } \\
\text { smokers } \\
(n=87)\end{array}$ & $\begin{array}{c}\text { Never- } \\
\text { smokers } \\
(n=1449)\end{array}$ & $\begin{array}{c}\text { Daily } \\
\text { smokers } \\
(n=618)\end{array}$ & $\begin{array}{c}\text { Occasional } \\
\text { smokers } \\
(n=359)\end{array}$ & $\begin{array}{c}\text { Ex- } \\
\text { smokers } \\
(n=81)\end{array}$ & $\begin{array}{c}\text { Never- } \\
\text { smokers } \\
(n=1004)\end{array}$ \\
\hline $\begin{array}{l}\text { Will certainly } \\
\text { smoke }\end{array}$ & 32.5 & 5.9 & 1.1 & 1.0 & 32.2 & 3.9 & 1.2 & 1.2 \\
\hline $\begin{array}{l}\text { Will probably } \\
\text { smoke }\end{array}$ & 14.5 & 8.3 & 2.4 & 0.8 & 15.0 & 9.5 & 1.2 & 1.4 \\
\hline $\begin{array}{l}\text { Will probably not } \\
\text { smoke }\end{array}$ & 22.4 & 14.9 & 8.0 & 10.2 & 25.6 & 16.7 & 4.9 & 12.8 \\
\hline $\begin{array}{l}\text { Will certainly not } \\
\text { smoke }\end{array}$ & 30.6 & 70.9 & 88.5 & 87.0 & 27.2 & 69.9 & 92.7 & 84.6 \\
\hline
\end{tabular}

Table 5 "How do you personally assess the importance of the reasons for not smoking yourself?" Percentage who answer "strongly agree" for each reason, among medical and nonmedical students according to smoking status (all years, universities and both sexes combined)

\begin{tabular}{|c|c|c|c|c|c|c|c|c|}
\hline & \multicolumn{4}{|c|}{ Medical students (\%) } & \multicolumn{4}{|c|}{ Nonmedical students $(\%)$} \\
\hline & $\begin{array}{c}\text { Smokers } \\
(n=1208)\end{array}$ & $\begin{array}{c}\text { Ex- } \\
\text { smokers } \\
(n=104)\end{array}$ & $\begin{array}{c}\text { Never- } \\
\text { smokers } \\
(n=1761)\end{array}$ & $(p)$ & $\begin{array}{c}\text { Smokers } \\
(n=895)\end{array}$ & $\begin{array}{c}\text { Ex- } \\
\text { smokers } \\
(n=96)\end{array}$ & $\begin{array}{c}\text { Never- } \\
\text { smokers } \\
(n=1226)\end{array}$ & $(p)$ \\
\hline To protect your health & 65.2 & 74.5 & 80.6 & $<0.001$ & 66.9 & 80.2 & 83.2 & $<0.001$ \\
\hline $\begin{array}{l}\text { Occurrence of certain } \\
\text { symptoms }\end{array}$ & 67.4 & 59.7 & 63.4 & NS & 66.3 & 59.7 & 62.9 & NS \\
\hline Good example for children & 53.2 & 46.8 & 55.0 & NS & 39.8 & 39.7 & 44.3 & NS \\
\hline Self-discipline & 32.5 & 51.5 & 47.0 & $<0.001$ & 33.4 & 43.3 & 44.6 & $<0.001$ \\
\hline Good example for patients & 28.8 & 28.0 & 33.7 & $<0.05$ & - & - & - & - \\
\hline Not to create discomfort & 22.3 & 17.5 & 28.0 & $<0.01$ & 23.3 & 16.6 & 30.7 & $<0.001$ \\
\hline $\begin{array}{l}\text { Good example for health } \\
\text { workers }\end{array}$ & 19.5 & 25.0 & 26.2 & $<0.001$ & - & - & - & - \\
\hline Good example for adults & 18.9 & 19.2 & 26.8 & $<0.001$ & 23.3 & 26.3 & 31.8 & $<0.01$ \\
\hline To save money & 14.8 & 12.3 & 16.0 & NS & 20.7 & 20.4 & 20.5 & NS \\
\hline Pressure of colleagues & 6.6 & 7.4 & 5.5 & NS & 9.0 & 7.1 & 10.7 & NS \\
\hline
\end{tabular}

Response choices are "strongly agree", "somewhat agree”, “somewhat disagree", "strongly disagree”.

years' time?" (table 4) did not differ between medical and nonmedical students; however, students' responses were closely related to their smoking status $(\mathrm{p}<0.001)$. The proportion of medical students who intended not to smoke by the end of five years was $30.6 \%$ among daily smokers, $70.9 \%$ among occasional smokers and $88.5 \%$ among ex-smokers. The response patterns to the above question did not differ by university or by gender $(p>0.05)$.

\section{REASONS FOR NOT SMOKING}

The two reasons for not smoking found to be most important for both medical and nonmedical students were "appearance of smoking-related disease symptoms" and "protection of their health" (table 5). Smokers were generally less likely to find important the usually accepted reasons for not smoking than were either ex-smokers or never-smokers. Medical students found such occupationally related reasons as "to set a good example for their patients" and "to set a good example for health workers" less important. In ordering importance of reasons given for not smoking, medical and nonmedical students were very similar.

KNOWLEDGE OF THE DANGERS OF TOBACCO

In general, $88 \%$ of medical and $86 \%$ of nonmedical students thought that smoking was dangerous to health $(\mathrm{p}>0.05)$. Medical students from different universities had similar beliefs about the dangers of smoking, but female medical students $(90 \%)$ were slightly more likely to find smoking dangerous than males $(86 \%)(p<0.05)$. However, in nonmedical students there was no sex difference ( $p$ $>0.05$ ).

Table 6 shows the proportion of students agreeing or disagreeing that smoking is a major cause of the listed diseases according to curriculum year and type of school. The association of some diseases with cigarette smoking was more likely to be known by the medical students in later years, but this was not true for pulmonary emphysema, any softtissue lesions (mouth/lip) or neonatal death. The pathogenic role of smoking on emphysema was only known by $21.8 \%$ (range $15.5-33.6 \%$ 
Table 6 Percentage answering "Yes" to the question, "Is cigarette smoking a major cause of these diseases?" by type of schools and curriculum year, all universities combined

\begin{tabular}{|c|c|c|c|c|c|c|c|}
\hline \multirow[b]{2}{*}{ Disease } & \multicolumn{4}{|c|}{ Medical students (\%) } & \multicolumn{3}{|c|}{ Nonmedical students (\%) } \\
\hline & $\begin{array}{l}\text { First year } \\
(n=1068)\end{array}$ & $\begin{array}{c}\text { Fourth year } \\
(n=1235)\end{array}$ & $\begin{array}{l}\text { Final year } \\
(n=770)\end{array}$ & $(p)$ & $\begin{array}{l}\text { First year } \\
(n=1366)\end{array}$ & $\begin{array}{l}\text { Final year } \\
(n=1035)\end{array}$ & $(p)$ \\
\hline Lung cancer & 63.1 & 76.8 & 70.4 & $<0.001$ & 66.0 & 69.8 & NS \\
\hline Chronic bronchitis & 23.2 & 59.2 & 59.7 & $<0.001$ & 27.1 & 32.0 & $<0.05$ \\
\hline Oral cancer & 23.4 & 30.3 & 34.1 & $<0.001$ & 27.1 & 31.2 & $<0.05$ \\
\hline Pulmonary emphysema & 26.7 & 26.3 & 21.8 & $<0.05$ & 33.8 & 36.4 & NS \\
\hline Laryngeal cancer & 29.3 & 44.7 & 50.1 & $<0.001$ & 33.4 & 38.0 & $<0.05$ \\
\hline Coronary artery disease & 23.4 & 31.2 & 34.8 & $<0.001$ & 33.6 & 33.0 & NS \\
\hline Leukoplakia (mouth-lip) & 16.8 & 16.4 & 20.2 & NS & 22.7 & 21.0 & NS \\
\hline Soft tissue lesion & 12.3 & 9.8 & 11.5 & NS & 16.2 & 15.1 & NS \\
\hline $\begin{array}{l}\text { Peripheral vascular } \\
\text { disease }\end{array}$ & 15.3 & 30.4 & 39.0 & $<0.001$ & 22.6 & 23.3 & NS \\
\hline Neo-natal death & 12.0 & 6.3 & 6.0 & $<0.001$ & 15.4 & 13.6 & NS \\
\hline Bladder cancer & 5.2 & 8.0 & 13.7 & $<0.001$ & 10.1 & 8.5 & NS \\
\hline
\end{tabular}

Table 7 Percentage of medical students answering "Often" to the question "In these three situations would you, as a future doctor, advise patients against smoking?" according to smoking status and curriculum year, males and females combined (all medical schools)

\begin{tabular}{|c|c|c|c|c|c|c|c|}
\hline \multirow[b]{2}{*}{ Situation } & \multicolumn{4}{|c|}{ Smoking status $(\%)$} & \multicolumn{3}{|c|}{ Curriculum year $(\%)$} \\
\hline & $\begin{array}{c}\text { Smokers } \\
(n=1178)\end{array}$ & $\begin{array}{c}\text { Ex- } \\
\text { smokers } \\
(n=103)\end{array}$ & $\begin{array}{c}\text { Never- } \\
\text { smokers } \\
(n=1715)\end{array}$ & $(p)$ & $\begin{array}{l}\text { First } \\
\text { year } \\
(n=1021)\end{array}$ & $\begin{array}{c}\text { Final } \\
\text { year } \\
(n=755)\end{array}$ & $(p)$ \\
\hline $\begin{array}{l}\text { 1. When patients have symptoms or confirmed } \\
\text { diagnosis of smoking-related diseases }\end{array}$ & 93.0 & 90.1 & 95.3 & $<0.01$ & 92.9 & 95.4 & $<0.05$ \\
\hline $\begin{array}{l}\text { 2. When the patient himself raises the question } \\
\text { about smoking }\end{array}$ & 77.8 & 82.5 & 85.4 & $<0.001$ & 76.1 & 85.9 & $<0.01$ \\
\hline $\begin{array}{l}\text { 3. When a patient is a smoker who has no } \\
\text { symptoms or diagnosis of smoking-related } \\
\text { diseases and does not himself raise the question } \\
\text { of smoking }\end{array}$ & 36.5 & 47.0 & 49.4 & $<0.001$ & 41.7 & 43.1 & NS \\
\hline
\end{tabular}

Response choices are "often", "sometimes", "seldom", "never".

for different universities), on coronary artery disease by $34.8 \%$ (range $30.0-50.5 \%$ ) and on bladder cancer by $13.7 \%$ (range $8.3-23.1 \%$ ) of final year medical students.

In nonmedical schools, the extent of knowledge on the major role played by cigarette smoking in the diseases given in table 6 did not change according to curriculum year, except for chronic bronchitis, cancer of the mouth and laryngeal cancer.

\section{ATTITUDES OF STUDENTS TOWARDS PATIENTS' SMOKING}

Students, as future doctors, were asked whether or not they would advise patients against smoking under three different situations. Those responding "often" are given in table 7 by smoking status and curriculum year.

Smoking medical students were less likely than never-smokers to advise patients with smoking-related diseases against smoking ( $\mathrm{p}<$ 0.01 ). A significant increase in the proportion of students advising patients against smoking was observed as the years of schooling increased. For a patient without a smokingrelated condition, and not raising the question himself, responses were similar for first and final year students $(p>0.05)$. Within each smoking status category, responses of male students for the three situations did not differ from female students $(p>0.05)$.

DOCTORS AND ANTISMOKING CAMPAIGNS

Students were given nine propositions concerning the role of doctors in antismoking campaigns and asked to indicate the extent to which they agreed or disagreed with each propositions. The proportion of students responding "strongly agree", by smoking status and curriculum year, is given in table 8 .

The attitudes of medical students toward the role of doctors in antismoking campaigns was generally affected by their own smoking behaviour. Smoking students were less likely than nonsmoking students to believe in the doctors' role ( $p<0.001)$. First- and final-year students had similar beliefs regarding the doctors' role. A significant increase in the proportion of students who found their knowledge a sufficient basis for counselling patients who wanted to stop smoking was observed, $13.2 \%$ in the first year and $52.4 \%$ in the final year $(\mathrm{p}<0.001)$ (table 8$)$.

Attitudes to the majority of propositions were similar among first-year medical students from different universities but there was significant inter-university variability among final-year students $(\mathrm{p}<0.05)$.

\section{ATTITUDES TOWARDS LAWS AND REGULATIONS} FOR CONTROLLING SMOKING

Students were given seven propositions for controlling smoking through legislative action and asked to indicate the extent to which they agreed or disagreed with each proposition. The proportion of medical and nonmedical students responding "strongly agree" by smoking status and curriculum year is given in table 9.

The propositions for controlling smoking were supported by the majority of both medical 
Table 8 "Indicate the extent to which you agree or disagree with each of the statements" Percentage of medical

Table 9 "A number of opinions have been expressed about how to reduce smoking through legislative action. Would you agree or disagree with the following opinions?" Percentage of medical $(M)$ and nonmedical $(N M)$ students answering "Strongly agree" according to their smoking status and curriculum year, males and females combined (For every opinion, two figures are given. The upper row relates to medical students, the lower row (in parentheses) to nonmedical students.)

\begin{tabular}{|c|c|c|c|c|c|c|c|c|}
\hline & & Smoking st & $\operatorname{atus}(\%)$ & & & Curriculum yed & $r(\%)$ & \\
\hline & $\begin{array}{c}\text { Smokers } \\
M(n=1181) \\
N M(n=944)\end{array}$ & $\begin{array}{c}\text { Ex- } \\
\text { smokers } \\
M(n=103) \\
N M(n=93)\end{array}$ & $\begin{array}{c}\text { Never- } \\
\text { smokers } \\
M(n=1714) \\
N M(n=1202)\end{array}$ & $(p)$ & $\begin{array}{c}\text { First } \\
\text { year } \\
M(n=1034) \\
N M(n=1273)\end{array}$ & $\begin{array}{c}\text { Fourth } \\
\text { year } \\
M(n=1204) \\
N M(n=966)\end{array}$ & $\begin{array}{c}\text { Final } \\
\text { year } \\
M(n=760)\end{array}$ & $(p)$ \\
\hline There should be a health warning on & 45.0 & 55.3 & 54.4 & $<0.001$ & 52.8 & 47.0 & 54.0 & $<0.01$ \\
\hline igarette packages & $(42.2)$ & (41.9) & $(51.0)$ & $<0.01$ & $(45.6)$ & (48.9) & - & NS \\
\hline 2. There should be a complete ban on the & 59.6 & 69.9 & 63.4 & $<0.05$ & 58.3 & 63.8 & 64.9 & $<0.01$ \\
\hline advertising of tobacco & $(53.5)$ & $(61.2)$ & $(59.8)$ & $<0.05$ & $(56.1)$ & $(58.8)$ & - & NS \\
\hline 3. Smoking in closed public places should & 75.8 & 91.2 & 93.6 & $<0.001$ & 87.2 & 85.6 & 87.3 & $\begin{array}{l}\text { NS } \\
\text { NS }\end{array}$ \\
\hline be restricted & $(68.2)$ & $(88.0)$ & $(90.4)$ & $<0.001$ & $(80.9)$ & $(81.1)$ & $\overline{252}$ & $\begin{array}{c}\text { NS } \\
<0.01\end{array}$ \\
\hline $\begin{array}{l}\text { 4. The price of tobacco products should be } \\
\text { increased sharply }\end{array}$ & $\begin{array}{c}17.1 \\
(19.9)\end{array}$ & $\begin{array}{l}35.2 \\
(31.5)\end{array}$ & $\begin{array}{c}34.8 \\
(40.6)\end{array}$ & $\begin{array}{l}<0.001 \\
<0.001\end{array}$ & $\begin{array}{c}32.4 \\
(33.3)\end{array}$ & $\begin{array}{c}25.7 \\
(29.2)\end{array}$ & $\underline{25.2}$ & $\begin{array}{l}<0.01 \\
<0.05\end{array}$ \\
\hline 5. The sale of tobacco to children should & 65.4 & 72.8 & 71.0 & $<0.01$ & 68.2 & 68.0 & 71.1 & NS \\
\hline be completely prohibited & $(63.5)$ & $(65.2)$ & (73.3) & $<0.001$ & $(66.6)$ & (71.9) & - & $<0.01$ \\
\hline 6. Smoking in hospitals should be & 79.4 & 84.4 & 80.4 & NS & 77.3 & 80.6 & 83.3 & $<0.01$ \\
\hline restricted to special smoking areas & $(79.0)$ & (72.5) & $(80.0)$ & NS & $(77.8)$ & $(81.6)$ & - & $<0.001$ \\
\hline
\end{tabular}

Response choices are "strongly agree", "somewhat agree", "somewhat disagree", "strongly disagree".

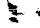

and nonmedical students. But the proposition "the price of tobacco products should be increased sharply" received minority support, by only $25.2 \%$ of final-year medical students and $29.2 \%$ of final- (fourth) year nonmedical students. Smoking students gave less support for legislative action than nonsmokers. When analysed within each smoking status category, legislative actions were equally likely to be supported by both medical and nonmedical, and by students from different universities ( $p$ $>0.05)$.

\section{Discussion}

In this study, seven universities, one from each of the seven different geographic regions of Turkey, were randomly selected to represent the 23 Turkish universities. The same ques- tionnaire and the same study protocol were administered and high participation was achieved. This made comparison of the findings from different universities possible and provided a reasonable sample for the country as a whole. Due to differences in age and male:female ratio of students from different universities, comparisons were made according to gender and curriculum year.

One would ideally conduct a longitudinal survey to track the behaviour, beliefs, and attitudes of students from the first to final years of school. However, in this study, including students from different curriculum years enabled us to compare behaviours and beliefs of first-, fourth-, and final-year students. Differences between the curriculum years were taken to reflect changes occurring over time, based on the assumption that the 
first-year values of the current fourth- and final-year students had been similar to those of current first-year students. Our assumption is supported by the fact that key aspects of the tobacco situation in Turkey have been stable for the past decade, including stable per capita cigarette consumption, the absence of effective antismoking activities, and on-going production, advertising and promotion of cigarettes in Turkey by international tobacco cartels.

Overall, smoking was much more prevalent among Turkish male medical students than among US, European, Australian, African, and Asian (but not Russian) counterparts. For female medical students, smoking was less prevalent than in Europe and Russia but more prevalent than in the US, Australia, Asia or Africa. ${ }^{5-8}$

Smoking rates (daily and occasional smokers combined) for medical students differed among the seven universities. This was mainly due to significant variations in smoking prevalence among male medical students. Rates for female medical students did not show such differences, indicating that female students were under more homogeneous influence of their cultural and social environment.

In Turkish society, smoking has been considered socially acceptable for men but not for women. In cross-sectional studies conducted in Turkey, the frequency of smoking has been found to be much higher for men than for women. As levels of education and urbanization increase, and Western values enter daily life, traditional culture, which puts pressure on women and children not to smoke, has been losing its effect. With increasing education and urban residence, the frequency of smoking for women and for young males has risen but the smoking behaviour of adult men living in socio-culturally different environments has not shown significant variation. ${ }^{9,10,13,14}$ In this study the finding of a twofold difference between male and female smoking rates, and the steeper increase in smoking rates for females than males according to curriculum year, seems to reflect these general trends in the population. With respect to male:female smoking ratios among medical students, Turkey was similar to Asian and African countries, but different from European countries, the US and Australia. ${ }^{5-8}$

High school graduates are eligible for university after they have passed a general entrance examination open to all graduates. Medical schools require a higher score for entry than did the nonmedical schools from which our sample was drawn. In a study conducted in Turkey on high school students, it was observed that the more successful the student was, the less likely he was to be a smoker. ${ }^{15}$ This may explain why first year medical students smoked less than first year nonmedical students. By the fourth year this difference has become nonsignificant, especially in males. This shows that in the university environment, where there was no family control and limited effective traditional culture, medical students tended to show a similar tendency to smoke as their counterparts in the general population. In addition, the absence of an antismoking climate within universities in Turkey, and the faculty as a role model for students (with over $50 \%$ smoking), may also have large influences on students' smoking behaviour. ${ }^{11}$

Contrary to observations made in European, Asian, African countries, the US, Australia and Japan, the smoking behaviour of medical students, especially in the final year was not much different from that of medical doctors or of the general population in Turkey; $62.8 \%$ of adult males ( $>15$ years), $62.4 \%$ of male medical doctors and $56.9 \%$ of male final year medical students were smokers (daily and occasional smokers combined). ${ }^{9,11,13}$ Female smoking rates were $24.3 \%$ of adult females, $44.1 \%$ of female doctors and $34.9 \%$ of female final year medical students. This suggests that the general tendency of the population plays a bigger role in the smoking behaviour of medical students than their medical education. This view was supported by our findings comparing medical and nonmedical students, as well as by the priority they gave to personal reasons rather than professional reasons for not smoking.

The proportion of students who knew about the association of smoking with certain diseases showed significant variation among universities. As in European, Asia, Africa, Australia and the US, there were major defects in knowledge among Turkish students.

There were also important defects in the knowledge of medical student as to the appropriate role of doctors in antismoking campaigns. Their views on this subject were highly influenced by their own smoking status but there was no difference between first- and final-year students. This shows that medical education in Turkey, as in Europe, Asia and Africa, failed to achieve positive behavioural changes against smoking. In Turkey, more final year medical students thought that they were equipped to counsel patients on smoking $(52.4 \%)$ than in European $(27.3 \%)$, Asian $(29 \%)$ or African ( $45 \%$ ) countries. In reported studies, less than half of final-year medical students $(41.3 \%$ of Turkish, $32 \%$ of European, $37 \%$ of Asian, and $31 \%$ of African) would advise patients to stop smoking if they had no smoking-related symptoms and did not raise the question themselves. ${ }^{5-7}$

In supporting legislative action against smoking, smokers, medical and nonmedical, were less eager than nonsmokers. The similarity of attitudes between first- and final-year students reflects a failure of current medical education to make students aware of the importance of such legislation.

This study shows that the epidemic of smoking, which has reached an important level in the Turkish population, is also reflected in the population of medical students. The data indicate that current education in Turkey has not prevented the smoking epidemic, even in medical students. The lack of well-organised and effective antismoking activities in Turkey is reflected in the behaviour and attitudes of medical students toward smoking, which are 
likely to be determined largely by trends in the general population. This suggests that medical education and antismoking activities taking place in Turkey should be reassessed as a matter of urgency. Intensive medical education on the subject should be scheduled for students, both in the early years and within clinical disciplines such as pulmonary medicine, cardiology, surgery, and internal medicine.

Tessier et al found differences in smoking prevalence among medical students in European, Asian and African countries. ${ }^{5-8}$ With respect to knowledge and behaviour toward smoking, medical students were similar in the three continents. It seems that most countries in the world have serious deficiencies in medical education on smoking. Future doctors are not equipped to deal effectively with the epidemic of smoking which is expected to worsen in the coming years. Cooperation between countries is urgently needed to overcome this problem.

In studies by Tessier et al, most countries were represented by only one university. In our study, we found variations in the results from medical students from seven different universities with respect to smoking behaviour, knowledge of the health effects of smoking, and beliefs about the appropriate role of doctors in prevention. These variations suggest that in international comparisons, the results from only one university may not always be representative of the country as a whole.

In our study medical and nonmedical students were found to be similar in contemplating quitting smoking, their reasons for not smoking, knowledge of the health hazards of smoking, attitudes towards legislative actions against smoking and, finally, their smoking behaviour in their final year. These findings help us to evaluate the effects of medical education. We conclude that, to investigate the effect of medical education on the knowledge, attitudes, and behaviour of students towards smoking, comparisons between students in medical and nonmedical schools are worthwhile.

We would like to thank Sir John Crofton and JF Tessier for their valuable contributions and editorial assistance. This study was supported by a grant (TF. 91.19) from the Cukurova University Research Fund.

1 Crofton J. Tobacco and the third world. Thorax $1990 ; 45$ : 164-9.

2 Scientific Council Report. The worldwide smoking epidemic. Tobacco trade, use and control. $\mathcal{F} A M A 1990$; 263: 3312-8.

3 Fiore MC, Pierce JP, Remington PL, Fiore BJ. Cigarette smoking: the clinician's role in cessation, prevention and public health. Disease-a-Month 1990; April: 205-24

4 Prignot J. Responsibilities and potentials of physicians in the fight against smoking. Bull Int Union Tuberc Lung Dis $1990 ; 65(4): 38-44$

5 Tessier JF, Freour P, Crofton J, Kambou L. Smoking habits and attitudes of medical students towards smoking and antismoking campaigns in fourteen European countries. Eur $\mathcal{F}$ Epidemiol $1989 ; 5 ; 311-20$.

6 Tessier JF, Freour P, Belougne D, Crofton J. Smoking habits and attitudes of medical students towards smoking and antismoking campaigns in nine Asian countries. Int $\mathscr{f}$ and antismoking campaigns in

7 Tessier JF, Freour P, Nejiari C, Belougne D, Crofton JW. Smoking behaviour and attitudes of medical students towards smoking and antismoking campaigns: a survey in 10 African and Middle Eastern countries. Tobacco Control $1992 ; 1$ : 95-101.

8 Tessier JF, Freour P, Nejiari C, Belougne D, Crofton JW. Smoking behaviour and attitudes towards smoking of medical students in Australia, Japan, USA, Russia, and Estonia. Tobacco Control 1993; 2: 24-9.

9 Kocabas A. The smoking problem in Turkey. IUATLD News Bull Tobacco Health 1993; 6: 27-8.

10 Kocabas A, Burgut R, Bozdemir N. The effect of educational status on cigarette smoking behaviour. Eur Respir ¥ 1993; 6(suppl 17): 610s (abstr).

11 Ardic S, Ozdamar N, Dinçer KS et al. Smoking habits and pulmonary function tests of physicians (Turkish). Solunum Hastaliklari 1990; 1(suppl 2): 51 .

12 World Health Organisation. Guidelines for the conduct of tobacco-smoking surveys among health professionals. Geneva: WHO, 1984 (WHO/SMO/84.1)

13 Smoking habits and attitudes of Turkish population towards smoking and antismoking campaigns: a report of Turkish Health Ministry (Turkish). Ocak: PIAR, 1988

14 Sezer RE. Smoking habits and reasons for smoking of secondary and high school students in Ankara. Doa 1984; 8(3): 375-84.

15 Kocabaş A. Smoking habits of secondary and high school students related to school activities and some family characteristics. I Fac Med, Univ Ankara, 1988; 41: 41-54. 